\title{
Phenomenological description of PTSD through a case
}

\author{
Descrição fenomenológica do TEPT por meio de um caso
}

\author{
Helio Rocha Neto ${ }^{1}$, Adonis Tomé ${ }^{2}$, Guilherme Peres Messas ${ }^{3}$
}

\footnotetext{
${ }^{1}$ Médico, psiquiatra e mestre em Psiquiatria pela UFRJ. Possui pós-graduação em psicopatologia fenomenológica pela Santa Casa de São Paulo e em preceptoria médica pelo Instituto Sírio Libanês. Atualmente cursa o doutorado em psiquiatria em regime de cotutela entre a UFRJ e Universidade de Lisboa, estudando modelos de entrevista diagnóstica em Psiquiatria. E-mail: hgrochaneto@gmail.com

${ }^{2}$ Psicólogo e pós-graduado em psicopatologia fenomenológica pela Santa Casa de São Paulo. Atualmente é professor-assistente da Universidade Paulista (UNIP) e colaborador da fundação Vunesp. Possui experiência na área de Psicologia, com ênfase em Intervenção Terapêutica, atuando principalmente nos seguintes temas: fenomenologia, saúde mental e educação. E-mail: adonismedicina@gmail.com

${ }^{3}$ Médico, psiquiatra, mestre e doutor em psiquiatria pela FMUSP, coordenador do curso de especialização em Psicopatologia e Saúde Pública e do curso de especialização em psicopatologia fenomenológica da Santa Casa de São Paulo. É ainda membro fundador da Sociedade Brasileira de Psicopatologia Fenômeno-Estrutural (SBPFE), e membro ativo da seção de filosofia e humanidades em psiquiatria da Associação Psiquiátrica Mundial e do centro de colaboração para práticas baseadas em valores na saúde e cuidado social, de Oxford. E-mail: gmessas@gmail.com
} 


\begin{abstract}
Post-traumatic stress disorder (PTSD) is a severe mental disorder described only by operational criteria, without a proper dialectic essential analysis. In this study, we present a typical PTSD case with psychotic features, describing his living world through the domains of Heideggerian ontological-existential constituents -spatiality, temporality, corporeity and interpersonality (being-with-others). A phenomenological reduction and diagnostic elaboration was then performed. An essence of pervasive fear, that locks all intentionality and taints the entire beingin-the-world is described as the main characteristic of PTSD. The differential diagnosis is then discussed through a temporal perspective, showing essential differences among Bipolar Disorder, Schizophrenia and Persistent Delusional Disorder. We stand for a return to phenomenology, and its use to diagnosis and disorder description as a way to improve diagnostic validity and reliability.
\end{abstract}

Keywords: Post-Traumatic Stress Disorder; Psychopathology; Differential Diagnosis; Schizophrenia; Phenomenology.

\title{
Resumo
}

O Transtorno do Estresse Pós-Traumático (TEPT) é um transtorno mental grave descrito apenas por critérios operacionais, sem uma análise essencial dialética adequada. Apresentamos neste estudo um caso típico de TEPT com traços psicóticos, descrevendo o mundo vivido pelo paciente por meio dos âmbitos das constituições ontológico existenciais heideggerianas - espacialidade, temporalidade, corporeidade e interpessoalidade (ser-com-outro) -, seguido de redução fenomenológica e elaboração diagnóstica. Uma essência de medo pervasivo, que bloqueia toda a intencionalidade e contamina todo o ser-no-mundo, é descrita como a principal característica do TEPT. O diagnóstico diferencial é então discutido por meio da perspectiva temporal, mostrando diferenças essenciais dos diagnósticos de Transtorno Bipolar, Esquizofrenia e Transtorno Delirante Persistente. Defendemos um retorno à fenomenologia e seu uso para o diagnóstico e a descrição de doenças como forma de melhorar a validade e a confiabilidade diagnóstica.

Palavras-chave: Transtorno do Estresse Pós-Traumático; Psicopatologia; Diagnóstico diferencial; Esquizofrenia; Fenomenologia. 


\section{Introduction}

Post-Traumatic Stress Disorder (PTSD) is a severe and disabling mental disorder (Bryant et al., 2016). Described as a consequence of surviving or witnessing life-threatening situations (American Psychiatric Association. DSM-5 Task Force, 2013; World Health Organization, 1992, 2018), many studies have shown a high prevalence of PTSD in disaster survivors, and responding officers (Berger et al., 2012; Durkin, 1993). Urban violence is another common cause of the disorder, resulting in a silent plague in many cities around the world (Corbin et al., 2013). A Brazilian study with civilians has shown urban violence as the leading cause of PTSD in that country, with $86 \%$ of the urban population exposed to some aggression, and an estimated prevalence around $10 \%$ of that sample (Luz et al., 2016).

Although interest and research in PTSD has increased after the Vietnam (McHugh \& Treisman, 2007) and Persian Gulf Wars (Hyams, 1996), it is not a newly described disorder. Da Costa Syndrome, Shell Shock disease, War neurosis, "neurosis de angústia" and "reacción de sobresalto" are just some of the names that could match a previous description of what we now call PTSD (Hoffert, 2014; Hyams, 1996; Lopez-Ibor, 1948). Nowadays, it is considered a neurotic disorder with a strong association to adrenergic arousal and its influence on Central Nervous System (Weathers, 2017). Development of categorical diagnostic criteria has followed such interest, pretending to solve validity and reliability problems, but numerous controversies about the nature of the traumatic event and the description of the disorder persist to this day (Brewin et al., 2017; McHugh \& Treisman, 2007).

Such controversies are not exclusive of PTSD and go back to the diagnostic crisis of psychiatry in the 70's decade. Back then, the absence of a unified diagnostic criteria and use of same semiologic/psychopathologic term for different phenomena resulted in a low agreement between examiners, leading to a crisis of trust in psychiatry as a scientific discipline (Andreasen, 2007). An example was the experiment of Rosenhan, where eight actors were sent to twenty emergency departments in the United States, resulting in eighteen hospitalizations and many diagnoses of psychosis in a sample of healthy subjects (Rosenhan, 1973).

The development of a structured diagnosis was proposed as a solution to the reliability problems, resulting in the development and publication of DSM - III (Wilson, 1993). It is considered a turning point between a philosophical, not scientific, and speculative psychoanalytic influenced psychiatry and an evidence-based, scientific medicine discipline (Andreasen, 2007; Wilson, 1993). The emphasis in a simplified and atheoretical criteria has its toll, however, and now several authors question the overgrowth in the amount of described 
mental disorders, the reduction of psychopathology abilities of the new doctors and, finally, the validity of some diagnosis. This matter does not seem to be solved by the newer versions of DSM and ICD (Andreasen, 2007; Jablensky, 2016; McHugh \& Treisman, 2007; Parnas, 2011; Parnas, Sass, \& Zahavi, 2013).

Such epistemological issues refer to Dilthey's postulates (Franco, 2012), outlined by Heiddeger (Peres, Assis and Machado, 2019). Such authors explain that the natural sciences, in which the descriptive categorial systems of ICD/DSM are based, are prized to be explanatory, with the objective of formulating explanatory, predictive and universal causal laws. In the case of mental health, it serves to explain general causes and to forecast behavior.

The "human sciences", on the other hand, value the understanding of the object of study, not by categorizing its dimensions, but covering its entire historical context. Such emphasis leads to a comprehensive analysis, that encompasses the whole cultural/historic context from a subject.

Natural sciences method is an interesting approach both for clinical semiology and for a disorder construct elaboration but fails to evaluate the whole complexity of illness experience, with consequences for diagnostic validity and reliability. Parnas and others defend a return to continental phenomenology as a path to improve diagnostic validity and reliability (Aboraya, et al 2005; Messas, Fulford, \& Stanghellini, 2017; Parnas et al., 2013). Stanghellini also advocates the use of structural psychopathology as a better method to describe mental disorders and to summarize patients' complaints, reinforcing the contextualized comprehensive view, in Dilthey's epistemology (Stanghellini, 2010).

Although not being exactly a "new disorder," PTSD lacks a phenomenon-structural description. Its construct relies only in its operational diagnostic criteria, resulting in a shallow and an incomplete diagnostic portrayal that deserves a better elaboration. The aim of this study is to present a typical phenomenon-structural analysis of PTSD through a clinical case and to discuss its complex and not operationally described presentation.

\section{Method}

The typical structure of a PTSD patient will be here presented through a clinical case. It was evaluated as a part of standard clinical attention in the Community's Mental Health Unit (Centro de Atenção Psicossocial - CAPS) in Santos, Brazil. CAPS is a multi-professional unit aimed to assist complex mentally ill patients, acting as a substitute to a hospital-based mental care health system (Koda \& Fernandes, 2007). Despite describing a patient impaired by his 
disorder, this case is not particularly severe, and the impairments and complaints of the patient are as similar as the ones of many other patients seen in that unity, with the same diagnosis.

The interview followed the anamnese model suggested by Dalgalarrondo (2008), a descriptive psychopathology Mental State Exam (MSE) and elaboration of a psychopathological summary as described by Cheniaux (2011). This model allows a semi-structured interview, later complemented with a review of mental syndromes based on the Present State Examination Schedules for Clinical Assessment in Neuropsychiatry (PSE-SCAN) (Wing, 1990). The first author performed the clinical interview, the case management and the follow up. A semistructured narrative interview with McGill Illness Narrative Interview (M.I.N.I) (Groleau, Young, \& Kirmayer, 2006), Brazilian Version (Santiago, Clarisse; Leal, Erotilde; Serpa Jr, 2014), was performed to complement the analysis of the patient lived world by structural psychopathology model and to explore its presentation. This interview was recorded and transcribed for analysis. Phenomenologic elaboration was conducted following a dialecticessential perspective, with description through the main dimensions of the lived world (Messas, Tamelini, Mancini, \& Stanghellini, 2018).

The patient provided his consent for the present study and the ethical committee and research has analyzed and approved the protocol. Vital biographic data was omitted for anonymity preservation. Due to the need for conciseness, and to reduce patient exposition, only positive findings of the MSE and a small part from the narrative interview will be exposed.

\section{Case Report}

Patient has been followed as schizophrenic for many years, and reports for evaluation due to a change in the assistance service.

Identification: H., 48 years old, now married for the third time, two children; He has not completed his formal studies after abandoning elementary school at 5 th grade to work at the age of twelve (less than 7 years of formal scholar experience). He is retired from armed private security force and practices many Christian and Spiritualist religion.

Pathological background: Diabetes, hypertension, and dyslipidemia. Also, refers to learning disabilities related to calculus impairment. Denies any other health disturbances and use of substances.

Family background: Unknown references about his mother or her family. Abandoned by his mother after his father's death during childhood, with no memories of his parents. His father died due to alcoholic cirrhosis, probably suffering from alcohol-induced psychosis. Uncle and 
aunt diagnosed with schizophrenia. He was raised under the care of this aunt, to whom he is very close.

Social background: Patient lives in his own four-room house, shared with his wife. He has no hobbies or favorite leisure activities and he is not currently practicing any physical exercises. He also mentions a good, balanced and highly varied food intake habits. He was used to have many social connections, but now he is restricted at home, keeping occasional contact with his siblings and one friend that visits him.

Main complaint: "Fear of persecution"

History of complaints: Besides his learning disabilities, H. was able to develop an unimpaired social and productive life until his $29 \mathrm{~s}$. He was then working as a security enforcement in a local shop, when witnessed a gunfight between a bandit and a police officer. The officer became severely injured during the conflict but survived the event. Although the patient did not suffer any physical harm, he refers that the event had a huge emotional impact in his life. When he returned to work a few days later, he was constantly uneasy, feeling in the edge and over-alert, as if he were at the imminence of a catastrophe. After some weeks, the uneasiness sensation expanded to everywhere, and he became paranoid in the streets with a continuous sensation of being observed, followed, and monitored. During the same period, the patient started to present flashbacks of the gunfire and nightmares about being followed, harassed, injured, and killed. The patient affirms that he was followed by bandits inside the mall, started believing that black cars followed his movements on the streets and was always fearful that someone could kidnap him. After a year, he was not able to go back to work, resulting in job loss, social avoidance, and conflicts that ended his second marriage. Locked in his house for six months, $\mathrm{H}$. referred that gradually his uneasiness and persecution fear improved, and he was then able to work again, when he was invited to work as an armed security in a law department. There, he worked unimpaired for six years, married again and rebuilt his life. At the age of 36, a colleague was robbed during his shift, and H. started feeling paranoid again. He described himself as if he were being observed, monitored, always in the edge, although kept his job until some months later when he had a panic attack during his shift.

H. was sent home and kept close surveillance around his familiars. Believing that "bandits" would then kidnap his wife or children since he was no longer available, he even bought tracking devices to monitor them. The reduction of functionality resulted in marital conflicts that ended his second marriage, and, after this time, he never recovered. Since then, the patient keeps a low-profile routine, avoiding leaving his house, always vigilant, feeling tracked and observed. He believes that those bandits are always looking for him and keeping vigilance 
outside his house, seeking a chance to kidnap or kill him. He also describes the return of flashbacks about the gunfire, seeing people on the streets and inside his house (that were not observed by others), memory impairment, recurrent nightmares, waking up screaming, irritability, and certain emotional numbness.

H. complains that TV scenes of violence, daily journals, and loud sounds trigger his memories and so he no longer watches movies. He has been restricted to only watch cartoons or animal life documentaries at home. The patient denies self-harm habits, self-image and feeding disorders, sadness, panic attacks and anxiousness not related to paranoid ideas, episodes of mania, obsessive-compulsive symptoms, self-disorders, auditory hallucinations, substance abuse, and suicidal thoughts or attempts.

\section{Mental Status Examination}

The patient arrives on time with his wife and sits in the waiting room until called. He is a medium size eutrophic black male, well-kept and wearing clothes that are appropriate for the occasion. H. seems uneasy, always looking around, avoiding eye contact with other patients or professionals, looking at the floor. When invited, he arises with his wife and comes to the interview room looking afraid and uncomfortable, although he introduces himself and greets me properly.

Once inside the room, it is possible to observe discrete mouth dyskinesia, that the patient does not seem to identify. Over alert, H. keeps looking at the door, and sometimes looking outside the windows losing details of what is being asked or what his wife is telling. For many times he is not able to remember (or seems confused about) the details when asked questions about his personal life, which annoys him and results in memory complains.

He identifies the origin of his mental health issues to the gunfire episode, describing a vague and loosely elaborated, but undoubtedly delirious paranoid idea of persecution. His speech is clear, linear, and easy to comprehend using simple and not always grammatically correct Portuguese. H. agrees that he has some "persecution mania," that brings him limitations, but seems irreducible about his conviction that he is being followed and monitored by a bandit gang. When describing his feelings, it is not possible to observe them in his facial or gestural mimicry, which is always locked in a fearful and avoidant instance.

When asked why he keeps looking everywhere, H. says that he is worried that someone could be recording him or could enter in the room to attack him or his wife. He even states that he is not comfortable to talk to me since he is not sure whether I will give information to his enemies. It is not possible to determinate if his behavior is secondary to over alertness or to a 
hallucinatory response. He wishes that he could somehow get freed from his fears and return to a healthy life where he was able to go outside his house alone and engage in social contact or even work.

\section{Psychopathology Summary (Cheniaux, 2011)}

Attitude: Suspicious, avoidant, afraid; Attention: Over vigilance with low tenacity; Perception: Nonspecific visual hallucinations. Possible hallucinatory behavior; Thought: normal Course and Form. Content: Delusional ideas of persecution. Overvalued ideas of life risk; Intelligence: Lightly reduction of global capacity, less than his scholarship; Memory: Evocation impairment, intrusive memories related to violence exposition; Language: Hypoprosody, speech instability with an aspect of insecurity; Humor and affect: Depressed, fearful, numb; Psychomotricity: Hands' stereotypy, orofacial tardive dyskinesia, uneasiness; Self-conscience: Temporal fragmentation, self-references.

The physical examination had shown nothing remarkable, except a high cardiac rate (120 bpm), that was later verified by Electrocardiogram as sinus tachycardia.

\section{Further evaluations}

When admitted, H. was using $60 \mathrm{mg}$ of fluoxetine and $3 \mathrm{mg}$ of risperidone daily, and complained of no improvement, although taking such medications for almost nine years by now. Both medications were suspended along four weeks, with no differences in his paranoia or functionality. Then he started treatment with sertraline $200 \mathrm{mg}$ and propranolol $40 \mathrm{mg}$ daily, as well as chlorpromazine. The chlorpromazine was prescribed as hypnotic, because of night attacks related to his nightmares. Over the following months, H. experienced dissolution of nightmares and reduction of flashbacks, especially after adjustment of propranolol to $80 \mathrm{mg} / \mathrm{day}$, which reduced his heart frequency to under $80 \mathrm{bpm}$ and the use of an off- label dose of $300 \mathrm{mg} /$ day of sertraline. As the dyskinesia eventually appeared again, chlorpromazine was exchanged for clonazepam. He was then able to walk around his neighborhood by himself and felt more comfortable on a daily basis, reduced his needs to check continually for his wife and children safety. He was still limited in his functionality by not feeling confident about his safety.

Eventually, he started to complain about sexual disturbances that were related to the use of propranolol and sertraline. However, all experiences related to medicine's reduction led to a return of the symptoms. Far from asymptomatic, both he and his wife preferred to deal with this collateral effect by other means that not reducing the dose, since both of them understood that he had improved compared to his previous presentation. Over the last three years of following 
up, the patient has been slowly improving, being able to come to the appointments alone, presenting small and transitory relapses related to urban violence exposure, since his neighborhood surrounding is a drug dealer infested area.

\section{Description of the living world by phenomenological dimensions}

Temporality

As temporality, we will use Binswanger's interpretation of Heidegger and Husserl's postulate (Massimi, 2019; Evangelista, 2016; Dastur, 2015), referring to a pre-predicative understanding of what time means, breaking the chronological linearity and constituting an inherent dialectical movement for the existence of being-in-the-world. In the human temporality described by Heidegger, existence is a project and existing is being-possibility, which means that other ways to exist and behave are possible for the subject. From a psychopathological perspective, the patient changes his lived-past, giving his future a new conformation; it is not for us to affirm a re-signification of traumas, but the unveiling of new experiential meanings, resulting in an expanded being-possibility.

H. is now 48 years old. Considering normal structural development, he should be living a stable apogee, where his past provides a solid ground for the development of his life beingpossibilities, with many options of interest and intense dedication to projects that would build the bulk of his productive life. It should be a phase of great joy and full production, but it is not what was lived by him.

H. has not much more contact with his lived past other than the very moment that he witnessed the officer's fire shooting. He can remember some information about his infancy, but details are not accessible. It is not like he could not recollect that information, but he is locked in the presence of an imminent disaster that does not permit his attention and intentionality to anything else other than self-preservation. As someone who is falling off a cliff, nothing in his past could provide any help, motivation or be interesting enough to deserve attention at the this moment when his life is at great danger.

Similar reasoning could be used to access his lived future: there is no space for planning, desiring, dreaming, or hoping once he does not know whether he will be alive in the next second. All his future intentionality is aimed to avoid imminent death/aggression of himself or close relatives that he also fears are in danger. Locked in a present hypertrophied by fear, H. could not build anything new, or play any other role that is not the one of the survivor dealing with an overwhelming force that could annihilate him at any moment. 
Temporality is lived by him as an infinite present, with a past that is only felt like the last seconds related to the immediate awareness of perceived danger. Future is also no longer than the next immediate seconds, from where he can only await threat and try simple moves to defend himself.

On the phenomenological basis, both Heiddeger and Husserl (Peres, Assis \& Machado, 2019) follows the Aristotelian assumption that the past is only accessible by the lenses of the present. A dialectical movement to the open future, in a protension of projects at stake between the conditions of possibilities of the being-in-the-world and its facticity. In this case, what we see is a break in this movement. Clinical improvement could be observed as the return of some future movement, with new plans and objectives that are not related to the avoidance of imminent threat.

Spatiality

Spatiality, according to Heideggerian reasoning (Camasmie, 2014), is not a strictly geometric and physical space matter. One does not have to be in place or travel through spatiality but may have an opening of the being-in-the-world experience. The spatiality creates conditions for detachment/approximation possibilities and direction/organization in the surrounding world. Thus, it cannot be reduced to the physical position of the being-there but opens up in the unveiling of meanings related to the world. Therefore, the living space is linked with the affect disposition of being-in-the-world.

Described from a spatial perspective, the patient lived-world is clear and bright, but with hideouts from where many perils lurk, that makes him always alert. His alertness blesses him with an improved ability to perceive sounds, movements, or areas where a hidden attacker could jump in (identified by a hyper-vigilant state that makes him always aware of any modification in his surrounding). Unfortunately, this also lessens his ability to concentrate, bringing a severe impairment in his life's production. It also contributes to a constant source of disconnected pieces of information, which are rationalized through fear as the evidence of an imminent threat, driving to the construction of a living world where he is always being tracked, observed, and jeopardized.

His lived space suffered a contraction due to fear, and now he is only able to exist in safe and checked territory. Since the traumatic event, his lived world was progressively reduced by the need for protection and safety, until it was narrowed to his bedroom at the beginning of the treatment. Even after feeling more relaxed, with a small but noticeable symptom relief by medication, H. did not gain territory. He seemed to be relieved in his safe ground without fear, and to be slowly expanding his living world again, but with minimum trials around his house. It 
is as if he was scouting meter by meter, trying to be sure whether the surrounding areas are safe, before lowering his guard and allowing his free circulation again.

Although he has been circulating in some common areas around his house everyday by now, such as the bakery, the market, and his children's school, the territory that resembles the violent event is still amputated from his life. He consistently avoids police headquarters, police patrols or private security personnel surroundings. In this structure, it is possible to observe a restriction of the patient's "there-shared" ("aí-compartilhado" or shared lived reality/world) (Jardim, 2013) in the unveiling of his being-in-the-world, compromising his conditions of possibility. Recent experiences in which his wife tried to go with him to a mall resulted in a panic attack after just a few moments standing on shopping grounds.

\section{Interpersonality}

H. empathetic abilities seem preserved, as he shows no confusion or inability to understand others' feelings. Other than that, he is also able to demonstrate his feelings properly to another people and the interviewer, even if through some numbness. Interpersonal contact, however, seems to be contaminated by his fear. He seems suspicious, and always expecting to be threatened or attacked by the interviewer, around whom he is not comfortable.

This patient produces feelings, in the interviewer, of extreme compassion, as if he is dealing with an afraid child that deserves protection. It is possible that, here, his intellectual disabilities mark his contact with a permanent naive feeling that is observed as childishly. The fragility and afraid aspect of his interpersonal contact, however, is always perceived. H. avoids eye contact almost all the time, appearing to be worried with attracting some anger or eliciting some challenges that could offend the clinician.

The always-present fear seems to contaminate even other modalities of affect resonance. When smiling, H. do so as if worried about generating some negative feelings in the interviewer. He describes his feelings towards his wife and children as if numbed by other emotions and there may be a preponderance of fear and need for safety. It is clear that his paranoid concerns engulf loved ones, as it is shown by his needs of installing tracking applications in his wife and children's devices. That creates a pattern that divides people in two types: the loved ones, that need to be protected and are always in danger (due to their involvement with him); and the potentially dangerous ones, for whom he needs to use safeguards and always be suspicious of some threatening force. This aspect of H.'s lived world have shown little improvement since the beginning of treatment, except for a discrete improvement of interpersonal relationship with his medical assistant. 
Materiality (corporeality)

In the constitution of corporeality, Van den Berg (2000) elucidates the dialectical experience of being a body (lived body) and of having a body (experienced body). The first is a pre-reflective, an immediate everyday experience endowed primarily with aware perception of the world. Here, the notion of conversion or psychosomatic symptoms is discarded, but synthetic man-world immediacy is considered.

H. presence is elusive. He is neither heavy nor light weighted, but often too tense, contracted, and ready to run. He is always overdressed, with heavy jackets that build an image of an armor. His body fidget can be noticed as rubbing hands, avoiding eye contact, keeping a defensive posture during the whole interview.

When greeting, he, again, seems fleeting. Although not avoiding touch, he shakes hands from some distance. His movement is tense and quite calculated to permit him an escape route or some time to study a potential threat, that seems to be expected from everyone. His eyes are always screening the environment and appear startled, perplexed, searching for danger in every corner. All this alertness brings even physiologic response: H. was, before medicated, continuously tachycardic and under treatment for hypertension. It is as if he is always under high adrenergic influence. That would be the physiologic defensive response of run or fight expected from someone who has had just seen a threat.

\section{Phenomenological Reduction}

Through all living dimensions that could be analyzed in H., it is evident the presence of pervasive fear. Fear is ever-present and over-intense, contaminating all his existence, imprinting its marks and its consequences on his expectations, numbing his interpersonal contact, attracting all his intentionality to the immediate need of defense. That causes impairment in his building abilities, and even in his reasoning that are sometimes fragile, almost fragmented and locked in a continual state of defense.

For Heidegger (Evangelista, 2016), fear as a "state of mind", when felt, does not necessarily reveal something fearful in the world, but a threat to our projective future existence. In the case of H., in a phenomenological analysis, Heidegger's fear concept does not explain the normality or pathology of his fear, but the understanding of the frightening experience in his structure of being-in-the-world. His traumatic experience makes his opening-to-the-world scared, as if he fears for his being-there. 


\section{Structural analysis}

This is a heavily defended and over-alert structure, with minimal possibilities of transcendence. Mobility is limited by the reassurance needs, contact with lived past and lived future is weak, since the defense from an immediate threat captures all intentionality. Nothing matters when under immediate danger. Although highly defended, the whole structure seems to shake and to be under risk of collapse once over-excited by environmental stimuli that can result in recurrent panic attacks.

\section{Diagnostic through structure analysis}

Phenomenological investigation shows a structure marked by intense fear and avoidance of an expected, although not necessarily present, threat. Some movement is possible, but under limited circumstances that require an abnormal amount of energy. Intentionality is locked in an ever-vigilant state that impairs its abilities to develop or acquire new traits. Second-guessing everything in the environment and any contact with others results in a paranoid state, which crystallizes as a delusion of persecution.

Fear and threat also contaminate his dreams outputs, evidenced by recurrent nightmares. Even though it is not present in this case, it would not be something unexpected from the reality relation in which intentionality appears to be shattered by the ever-shifting need for focus attention between reality calls (ex. Interpersonal contact) and threat avoidance. That could lead to thought disorganization and memory formation impairment, simulating formal thought disorder and amnesia. All this triggered by a violent event that ruptured his lifeline and caused a restraint in his structure. All the characteristics described above seem to be part of the typical structure of PTSD.

\section{Discussion}

Phenomenology is the philosophical background of continental psychopathology (Parnas, 2011; Stanghellini, 2009; Tonus \& Messas, 2018). Its use for the diagnostic procedures and disorder description, however, is quite complicated and requires adequate training. Besides that, using phenomenology for structural diagnosis and disorders description brings some advantages that are not available in operational criteria and even in descriptive psychopathology (Messas et al., 2018).

Both mainstream operational diagnostic systems, DSM-5 and ICD-10 (including its eleventh edition), describe PTSD through four dimensional symptoms "clusters": Intrusive rememoration (flashbacks, nightmares, etc.); avoidance of stimuli; mood/cognitive alterations 
and hyper-arousal (American Psychiatric Association. DSM-5 Task Force, 2013; World Health Organization, 1992). At least one symptom of each cluster must be present, starting or getting worse in a couple of days after a traumatic event and lasting for a month. However, from a structural perspective, it was shown that all these symptoms, like expressions of the being-inthe-world, are yet accessories to a persistent and pervasive fear, that had become pathologically part of a conscious structure.

Even worst, the presence of psychotic features, like delirious and hallucination of any kind, restricts diagnostic heuristics in categorical systems. Only schizophrenia spectrum disorders, affect disorders with psychotic features and persistent delusional disorder (PDD) may happen with such features. But here was shown a patient with a clinical background, evolution, and therapeutic response not compatible with none of these diagnostics.

Since categorical diagnostics system description of these disorders has already been criticized for having low validity (Aboraya et al., 2005; Jablensky, 2016), how could phenomenology contribute for this differentiation? Since our main hypothesis is that the essence of PTSD is a structure locked in a jeopardy instant, in temporal dimension analysis, it seems interesting to separate it from schizophrenia and affect psychosis through the aspect of time.

Melancholic depression and Mania have very well described temporal structure manifestations (Binswanger, 1964; Bloc et al., 2016; Sass \& Pienkos, 2013a). In melancholy, two temporal disturbances are evident: temporal flow reduction and hypertrophied past (Fuchs, 2001; Straus, 1960). In the first one, time became experienced as if running slow, making all expectations unnervingly distant and the present boring, accompanying the heaviness of body experience (Sass \& Pienkos, 2013b, 2013a).

The hypertrophied past presents itself with an overemphasis in felt and lived experiences, leading to rumination of old choices, failures and the "what if curse" (Fuchs, 2013). In other words, the temporal experience is that of the infiltration of retentive moments, perceiving the future as already realized, regardless of the real experience (Dastur, 2015).

A "slow pacing time" can be confounded with "frozen time", and it is not unusual that PTSD can be confounded or considered comorbid with depression in its clinical presentation (Campbell et al., 2007; Elhai et al., 2011). The same can be said about hypertrophied past, that resembles a "locked in a moment" experience, yet both are clinically different. Our PTSD case has no hypertrophied past, once he is not even totally capable to remember or access it, being locked in the very moment of danger and the immediate future where he might be dead.

Time compression phenomena is described as a lot of experiences lived in a single moment in traumatic experience and is common in PTSD (Fayolle, Gil, \& Droit-Volet, 2015). 
Time in PTSD is not experienced as a slow flow of experiences, but rather too fast. It is not like the minute lasts for over a day, but the day that is lived within a minute. In his case, it is not only an "as if" experience, but he is actually locked there, in the very same minute since all the events happened.

Mania can be described almost in the opposite sense of melancholic depression by time perspective: a future made present, with increased temporal flow rate (Binswanger, 1964; Ghaemi, 2006). Plans for the future become present so fast that patients usually experience their desire as already fulfilled, and it leads to delirious of power and grandiose (Sass \& Pienkos, 2013a). The "increase of time flow experience" is seen as an increased thinking process speed, speech and behavior that, many times, compromises the comprehension and leads to low pragmatism, despite the increased volition observed in body experience (Figueira \& Madeira, 2011; Sass \& Pienkos, 2013b).

The present case does have a rushed experienced time flow, but again, it is only locked in the immediate vicinity of the experience. That is not the same of what can be observed in mania, as it can be seem like the patient not being able to change his intentionality or even the content of his worries. It could be said that he lives a mono-thematic, ever-restarting immediate future in which he could be in danger, as having experienced the same event for many times in the same moment. These phenomena are really different from the ever changing and conquering experience of mania (Figueira \& Madeira, 2011; Ghaemi, 2006).

Schizophrenia is categorically described mainly as a delirious-hallucinatory syndrome, with thought disorganization components (American Psychiatric Association. DSM-5 Task Force, 2013). However, Parnas describes that these signs and symptoms are just secondary consequences of self-disorder and that these self-disorders are the clinical core of all schizophrenia spectrum disorders (Parnas, 2011; Parnas \& Handest, 2003; Sass \& Parnas, 2003). Although not developing a specific temporal description for schizophrenia, their work points out that the structural characteristic of schizophrenia is the impairment of the ability to integrate the various subtle, yet most fundamental subjective conscious experiences, as a result of lost ipseity (Møller, Haug, Raballo, Parnas, \& Melle, 2011; Parnas, 2011; Parnas \& Handest, 2003).

In EASE, it is described the delayed perception of mineness, and a multitude of timerelated experiences where it is felt as frozen, slow, or chronically rushed, between others (Parnas et al., 2005). Incapacity to deal with integration between lived experiences and time are the real problem in schizophrenia. Not only a time specific disturbance that could even appear as many types of temporal "as if" bizarre experiences. That is radically different from what has been shown in the present case.

Psicopatologia Fenomenológica Contemporânea, 2021;10(1):39-75 
Our patient surely has a lived time damage but is precisely the experience of ever being in the same jeopardy moment that is the characteristic of his lived experience and consciousness structure. It was not shown at any point of his history or mental examination the presence of any other alteration that could be described as self-disorder. His delusions and hallucinatory phenomena seem to be secondary to his structure damage, what is the only resemblance with schizophrenia (Parnas \& Sass, 2001).

Since the main characteristic of PDD is a well-structured, persistent, and usually monothematic delusion (American Psychiatric Association. DSM-5 Task Force, 2013; World Health Organization, 1992), it is hard to find a specific phenomenon-structural description to it, once delusion is considered a secondary phenomenological phenomenon (Parnas, 2004; Sass et al., 2013). Being clinically distinct from schizophrenia and affective psychosis, PDD is probably a single manifestation of other disorders with paranoid features, but with an otherwise preserved personality (Munro, 1991). It was shown here that our patient has a clear mono-thematic and persistent delusion, yet not possible to say that it is structured.

Once again, such phenomenon is secondary to different temporal characteristics. Whatever the mechanism of delusional development is (perceptual or rational disturbance) (Parnas, 2004), a structural time flow would be needed for its elaboration. PDD patients could not be so preserved if they were chronically paralyzed in a single existential moment. Being paralyzed on the very same moment in which his life was at risk, can easily explain the over alertness behavior and paranoid features described in the living world of our patient. That can be identified as a persistent delusion from an external observer, but it can also account for the absence of delusion enlargement (that would result in a systematized delusion), since his structure is immobilized in that moment.

Fear is usually described as an observed feature in spatial analysis of schizophrenic structure, as presented by Binswanger (2012) in Suzan Urban case. Temporal analysis of anxious patients (Aho, 2018), and spatial structure interactions of melancholic (Tellenbach, 2014) also bring its traces. However, it is necessary to say that, in PTSD, fear is not part of a response to an abnormal lived world, as it is in schizophrenia. In that case, it happens to be a response to the lack of contact with reality that is characteristic of that disorder. In anxiety, it is a consequence of the overwhelming future preoccupation and in melancholia, a response to the dark, heavy, and sinister melancholic spatial dimension.

In PTSD, an intense, overwhelming, and ever-present fear is part of the structure, influencing all lived experiences of the subject. Such fear is also responsible for locking the structure in a singular life moment and for paralyzing existence development through 
intentionality restriction to defensive moves. Fear is not just a "state of mind", but a reflex of the PTSD structure's way of being-in-the-world, manifested as a taint in its openness to existence in conscious constitution. This is the phenomenological essence of PTSD.

\section{Conclusion}

Categorial diagnosis, although considered a revolutionary turning point in modern psychiatry, suffers from validity issues (Andreasen, 2007; Jablensky, 2016; Parnas, 2011; Parnas et al., 2013). We advocate a phenomenon-structural description as a more valid diagnostic construction than a checklist of symptoms. As it was shown in the present work, overemphasis in a specific sign or symptom makes the categorical system fragile and probably leads to validity and reliability issues.

In the analyzed case, the delusion was present and part of the PTSD presentation. Excluding the possibility of delusion from PTSD description probably results in wrong diagnose and inadequate treatment. Furthermore, no "formal thought disorder" was identified, and the reasoning presented here reinforces the theory of the psychological origins of delusion and repeals the idea of schizophrenia being related to PTSD (Seedat, Stein, Oosthuizen, Emsley \& Stein, 2003).

As far as these authors were able to track, no previous structural description of PTSD has been done. Here we present a phenomenon-structural analysis of a PTSD patient, that could be used as a starting point for future diagnostic discussion. As a preliminary model, it must be validated and further developed in other studies. We hope future developments in a phenomenonstructural standard description of PTSD can aid the diagnostic validity and reliability as well as improve research about this disorder. 


\section{Descrição fenomenológica do TEPT por meio de um caso}

\section{Introdução}

O Transtorno de Estresse Pós-Traumático (TEPT) é um transtorno mental grave e incapacitante (Bryant et al., 2016). Descrito como uma consequência da exposição à situação de risco a vida (American Psychiatric Association. DSM-5 Task Force, 2013; Organização Mundial da Saúde, 1992, 2018), muitos estudos mostram uma alta prevalência do TEPT em sobreviventes de desastres e profissionais de resgate (Berger et al., 2012; Durkin, 1993). A violência urbana é outra causa comum para o transtorno, resultando em uma praga silenciosa em muitas cidades ao redor do mundo (Corbin et al., 2013). Um estudo brasileiro com civis apontou a violência urbana como a principal causa de TEPT no país, com $86 \%$ da população urbana exposta a alguma agressão, e uma prevalência estimada em torno de 10\% dessa amostra (Luz et al., 2016).

Embora o interesse e a pesquisa no tema tenham aumentado após a Guerra do Vietnã (McHugh \& Treisman, 2007) e a Guerra do Golfo Pérsico (Hyams, 1996), não é um transtorno novo. A Síndrome de Da Costa, doença de impacto de artilharia, neurose de guerra, "neurose de angústia" e "reacción de sobresalto" são apenas alguns dos nomes que poderiam corresponder a uma descrição anterior do que hoje chamamos de TEPT (Hoffert, 2014; Hyams, 1996; LopezIbor, 1948). Atualmente, este é considerado um distúrbio neurótico, associado à excitação noradrenérgica e sua ação no Sistema Nervoso Central (Weathers, 2017). O desenvolvimento de critérios diagnósticos categoriais acompanhou esse aumento de interesse, pretendendo resolver problemas de validade e confiabilidade entre examinadores, mas inúmeras controvérsias sobre a natureza do evento traumático e a descrição do transtorno persistem até hoje (Brewin et al., 2017; McHugh \& Treisman, 2007).

Tais controvérsias não são exclusivas do TEPT, e nos remetem à crise de diagnóstico de psiquiatria na década de 1970. Naquela época, a ausência de critérios diagnósticos claros e o uso dos mesmos termos semiológicos/psicopatológicos para diferentes fenômenos mentais resultavam em uma baixa concordância entre examinadores, levando a uma crise de confiança na psiquiatria como disciplina científica (Andreasen, 2007). Um exemplo foi o experimento de Rosenhan, que enviou oito atores a 20 prontos-socorros nos Estados Unidos, resultando em 18 hospitalizações e muitos diagnósticos de psicose em uma amostra saudável (Rosenhan, 1973).

O desenvolvimento de diagnósticos estruturados foi proposto como solução para os problemas de confiabilidade, resultando no desenvolvimento e publicação do DSM - III (Wilson, 1993). Este é considerado um ponto de virada entre uma psiquiatria de influência psicanalítica e 
filosófica, não científica e especulativa, para uma disciplina de medicina científica baseada em evidências (Andreasen, 2007; Wilson, 1993). A ênfase em critérios simplificados e não embasados em teoria, contudo, traz prejuízos diversos.

Vários autores questionam o crescimento excessivo da quantidade de transtornos mentais descritos, e acusam o modelo criteriológico de ser responsável pela redução das habilidades em semiologia de novos médicos. Além disso, queixam-se da falta de validade de alguns diagnósticos (Andreasen, 2007; Jablensky, 2016; McHugh \& Treisman, 2007; Parnas, 2011; Parnas, Sass, \& Zahavi, 2013), o que não parece ter sido resolvido pelas versões mais recentes do DSM e da CID.

Tais questões epistemológicas remetem aos postulados de Dilthey (Franco, 2012) e delineados por Heiddeger (Peres, Assis e Machado. 2019). Estes explicam que as ciências naturais, nas quais o método descritivo criteriológico do DSM/CID são embasados, são valorizadas por possuírem o objetivo de formular leis explicativas e preditivas, de características universais. No caso da saúde mental, trariam explicações gerais sobre as causas e serviriam para a predição do comportamento humano.

Já as "ciências humanas", por outro lado, valorizam a compreensão do objeto de estudo, não categorizando suas dimensões, mas abrangendo todo o contexto histórico/cultural. Este enfoque leva a uma análise compreensiva, mas não explicativa, partindo da generalidade para o caso específico, enquanto o das ciências naturais partem do caso específico (lei) para generalizações (previsões).

A abordagem das ciências naturais é interessante tanto para a semiologia clínica quanto para a elaboração do constructo do transtorno, mas falha em acessar toda a complexidade da experiência de adoecimento, com prejuízo para a validade destes constructos. Parnas e outros autores defendem um retorno à fenomenologia continental como um caminho para melhorar a validade e a confiabilidade diagnóstica (Aboraya, et al 2005; Messas, Fulford, \& Stanghellini, 2017; Parnas et al., 2013). Stanghellini também defende o uso da psicopatologia estrutural como melhor método para descrever os transtornos mentais e as queixas dos pacientes (Stanghellini, 2010), reforçando a visão compreensiva contextualizada, na epistemologia de Dilthey, mencionada acima.

Não sendo exatamente um "novo transtorno", o TEPT carece de uma descrição fenômeno-estrutural, no entanto. Seu constructo depende apenas de seus critérios diagnósticos operacionais, resultando em uma descrição diagnóstica superficial e incompleta, que merece melhor elaboração. O objetivo deste estudo, assim, é apresentar uma análise fenômeno-estrutural 
do TEPT por meio de um caso clínico, e discutir sua apresentação complexa, não descrita operacionalmente.

\section{Método}

A estrutura típica de um paciente com TEPT será apresentada por meio de um caso clínico, acompanhado em um Centro de Atenção Psicossocial (CAPS) em Santos, Brasil. O CAPS é uma unidade multiprofissional voltada ao atendimento de pacientes com transtornos mentais complexos, atuando como substituto de um sistema de saúde hospitalar (Koda \& Fernandes, 2007). Apesar de ser um paciente com grandes limitações causadas pelo seu distúrbio, este caso não é particularmente grave e equivale como protótipo a muitos outros pacientes atendidos naquela unidade, com o mesmo diagnóstico.

A entrevista seguiu o modelo de anamnese sugerido por Dalgalarrondo (2008) e um Exame do Estado Mental (sigla do inglês: Mental State Exam - MSE) de psicopatologia descritiva com súmula psicopatológica conforme descrita por Cheniaux (2011). Este modelo permite uma entrevista semiestruturada, posteriormente complementada com uma revisão das síndromes mentais com base no Exame do Estado Atual (PSE-SCAN) de Wing (1990). O primeiro autor realizou a entrevista clínica e o acompanhamento do caso. A entrevista narrativa semiestruturada McGill Illness Narrative Interview (MINI) (Groleau, Young, \& Kirmayer, 2006), versão brasileira (Santiago, Clarisse; Leal, Erotilde; Serpa Jr, 2014), foi realizada para complementar a análise do mundo vivido pelo paciente, para o modelo de psicopatologia estrutural. Essa entrevista foi gravada e posteriormente transcrita para análise. A elaboração fenomenológica foi realizada seguindo uma perspectiva dialético essencial, com descrição por meio das principais dimensões do mundo vivido (Messas, Tamelini, Mancini, \& Stanghellini, 2018).

O paciente forneceu consentimento para o presente estudo e o comitê de ética e pesquisa analisou e aprovou o protocolo. Dados biográficos vitais foram omitidos para preservação do anonimato. Pela concisão, e para reduzir a exposição do paciente, apenas os achados positivos do MSE e uma pequena amostra da entrevista narrativa serão expostos.

\section{Relato de caso}

Paciente há anos em acompanhamento com o diagnóstico de esquizofrenia comparece devido à troca de serviço de assistência. 
Identificação: H., 48 anos, casado pela terceira vez, dois filhos. Abandonou o ensino fundamental na $5^{\mathrm{a}}$ série devido à necessidade de trabalhar aos 12 anos (menos de sete anos de escolaridade). Aposentou-se como segurança privado armado. Praticante de diversas religiões cristãs e espíritas.

Antecedentes patológicos: diabetes, hipertensão e dislipidemia. Refere a dificuldades de aprendizagem em matemática. Nega quaisquer outros distúrbios de saúde ou uso de substâncias.

Antecedentes familiares: não possui referências sobre a mãe ou sua família. Abandonado pela mãe após a morte do pai durante a infância, não possui recordações com os mesmos. $\mathrm{O}$ genitor morreu devido cirrose alcoólica, provavelmente sofrendo de psicose induzida pelo álcool. Tio e tia com esquizofrenia (SIC). Criado sob os cuidados desta tia, de quem é muito próximo.

Antecedentes sociais: paciente mora em casa própria com quatro cômodos, compartilhada com a esposa. Não tem hobbies ou preferências em atividades de lazer e não pratica exercícios físicos. Nega problemas alimentares. Contava com uma rede social ampla, mas atualmente está restrito à sua casa, com contatos ocasionais com os irmãos e um amigo que o visita.

Queixa Principal: "Medo de perseguição"

História da doença atual: Apesar de suas dificuldades de aprendizagem, H. foi capaz de desenvolver uma vida social e produtiva até os 29 anos. Trabalhava como vigilante em um shopping, quando testemunhou e foi encurralado num tiroteio entre um bandido e um policial. O oficial foi gravemente ferido, mas sobreviveu. Apesar de não ter sofrido nenhum dano físico, o paciente aponta que o evento teve um grande impacto emocional em sua vida. Quando voltou ao trabalho, sentia-se inquieto, no limite e alerta, como se na iminência de uma catástrofe. Depois de algumas semanas o mal-estar se agravou, sentindo-se paranoico nas ruas, com uma sensação contínua de ser observado, seguido e monitorado. No mesmo período, o paciente passou a apresentar flashbacks do tiroteio e pesadelos sobre ser seguido, assediado, ferido e morto. O paciente afirma que foi seguido dentro do shopping, acredita que carros pretos seguiam seus movimentos na rua e estava sempre com medo de ser sequestrado. Depois de um ano, ele não pôde mais voltar ao trabalho, o que resultou na perda do emprego, na evitação social e nos conflitos conjugais, levando ao fim de seu segundo casamento. Trancado em sua casa por seis meses, H. referiu que gradativamente seu mal-estar e medo da perseguição foram melhorando e voltou a trabalhar como vigilante em um departamento jurídico, onde trabalhou ileso por seis anos. Casou-se novamente e reconstruiu sua vida, quando aos 36 anos, um colega foi assaltado durante seu turno e H. voltou a se sentir paranoico. Ele diz que passou a ser observado e 
monitorado, abandonando o trabalho alguns meses depois, quando teve um ataque de pânico durante seu plantão.

Posteriormente, H. manteve vigilância estrita em torno de seus familiares, acreditando que "bandidos" sequestrariam sua esposa ou filhos, uma vez que ele não estava mais disponível, chegando a comprar dispositivos de rastreamento para eles. A redução da funcionalidade resultou em conflitos conjugais que acabaram com seu casamento, mas desta vez ele nunca se recuperou. A partir disso, o paciente mantém uma rotina discreta, evitando sair de casa, sempre vigilante, sentindo-se rastreado e observado. Acredita que os bandidos estão sempre procurando por ele e mantém vigilância do lado de fora de sua casa, em busca de uma chance de lhe sequestrar ou matar. Ele também descreve o retorno dos flashbacks, diz ter visto pessoas nas ruas e dentro de sua casa que não foram observadas por outras, queixa-se de dificuldades de memória, além de pesadelos recorrentes, de acordar gritando, de sentir-se irritado e com certa dormência emocional. H. reclama que cenas de violência na TV, noticiários e sons altos acionam suas memórias e, por isso, não assiste mais a filmes, ficando restrito a desenhos animados ou documentários sobre a vida animal. O paciente nega hábitos de automutilação, distúrbios de autoimagem ou alimentares, tristeza, ataques de pânico e ansiedade não relacionados às ideias paranoides, episódios de mania, sintomas obsessivos compulsivos, distúrbios do eu, alucinações auditivas, abuso de substâncias e tentativas ou pensamentos suicidas.

\section{Exame do Estado Mental (MSE)}

O paciente chega pontualmente com a esposa e fica sentado na sala de espera até ser chamado. É um homem negro, eutrófico, de tamanho médio, bem cuidado e vestindo roupas adequadas para a ocasião. H. parece inquieto, sempre olhando em volta, evitando o contato visual com outros pacientes ou profissionais. Ao ser convidado, ele se levanta com sua esposa e vem para a sala parecendo amedrontado e incomodado, mas se apresenta e cumprimenta o entrevistador adequadamente.

Uma vez dentro da sala, é possível observar discretas discinesias bucais, que o paciente parece não notar. Sempre em alerta, H. continua procurando a porta e às vezes olha para fora pelas janelas, perdendo detalhes do que foi perguntado ou do que sua esposa estava contando. Muitas vezes não conseguia se lembrar ou fica confuso quando questionado sobre detalhes de sua vida pessoal, o que o incomoda e resulta em reclamações sobre a memória.

Ele identifica a origem de seus problemas de saúde mental com o episódio do tiroteio, descrevendo uma ideia paranoide vagamente estruturada, mas, sem dúvida, delirante, de perseguição. Sua fala é clara, linear e de fácil compreensão em um português simples. H. 
concorda que tem alguma "mania de perseguição", o que lhe traz muitas limitações, mas parece irredutível sobre sua convicção de que está sendo seguido e monitorado por uma gangue. Ao descrever seus sentimentos, isto não é observável em sua mímica facial ou gestual, que parece sempre amedrontada e esquiva.

Questionado sobre por que fica olhando para todos os lugares, H. diz que está preocupado que pudesse ser gravado, ou que alguém possa entrar na sala para atacá-lo. Afirma que não se sente à vontade para falar, pois não tem certeza se essas informações não poderiam ser dadas aos seus inimigos. Não é possível determinar se seu comportamento é secundário a um estado de alerta excessivo ou à atividade alucinatória. Ele deseja que pudesse de alguma forma se livrar de seus medos e retornar a uma vida saudável, em que pudesse sair de casa sozinho, se envolver em contato social ou até mesmo trabalhar.

\section{Súmula psicopatológica (Cheniaux, 2011)}

Atitude: Suspeito, evasivo, com medo; Atenção: Vigilância excessiva com baixa tenacidade; Percepção: alucinações visuais inespecíficas, possível atitude alucinatória; Pensamento: Curso e Forma normais; Conteúdo: Delírio persecutório e ideias sobrevalorizadas de risco de vida; Inteligência: Redução leve da capacidade global, menos que seu nível de escolaridade; Memória: deficiência de evocação, memórias intrusivas relacionadas à exposição à violência; Linguagem: hipoprosódia, instabilidade da fala com um aspecto de insegurança; Humor e afeto: deprimido, com medo, entorpecido; Psicomotricidade: estereotipia das mãos, discinesia tardia orofacial, inquietação; Autoconsciência: fragmentação temporal, autorreferência.

O exame físico não mostra nada de notável, exceto por uma frequência de ritmo cardíaco elevada de 120, posteriormente verificada pelo ECG como taquicardia sinusal.

\section{Evolução clínica}

Ao ser admitido, H. usava $60 \mathrm{mg}$ de fluoxetina e $3 \mathrm{mg}$ de risperidona diariamente, e queixou-se de não sentir mudanças evolutivas, embora estivesse tomando tais medicamentos há quase nove anos. Ambos os medicamentos foram suspensos, sem diferenças em sua paranoia ou funcionalidade. Iniciou uso de sertralina $200 \mathrm{mg}$ e propanolol $40 \mathrm{mg} / \mathrm{dia}$, e clorpromazina como hipnótico, devido às crises noturnas relacionadas aos pesadelos. Nos meses seguintes, $\mathrm{H}$. experienciou resolução de pesadelos e redução de flashbacks, principalmente após ajuste do propranolol para $80 \mathrm{mg} / \mathrm{dia}$, que reduziu sua frequência cardíaca para menos de 80 , e o uso de uma dose off-label de 300mg/dia de sertralina. Como a discinesia apareceu novamente, a clorpromazina foi trocada por clonazepam. Ele foi então capaz de caminhar pelo seu bairro 
novamente e se sentiu mais confortável em seu cotidiano, reduzindo suas necessidades de verificar continuamente a segurança de sua esposa e filhos. Ele segue limitado em seu funcionamento e não tem certeza de que não é perseguido.

Eventualmente, passou a reclamar de distúrbios sexuais relacionados ao uso de propranolol e sertralina, mas todas as experiências de redução de medicamentos levaram ao retorno dos sintomas. Embora ainda sintomático, tanto ele quanto a esposa preferiram lidar com esse efeito colateral por outros meios que não a redução da dose, pois ambos entendiam que a melhora em relação à apresentação anterior era marcante. Nos últimos três anos de acompanhamento, o paciente vem melhorando aos poucos, comparecendo sozinho às consultas, com recaídas pequenas e transitórias relacionadas à exposição à violência urbana, já que reside em uma área de tráfico de drogas.

\section{Descrição do mundo vivido por dimensões fenomenológicas}

Temporalidade

Como temporalidade, utilizaremos a interpretação de Binswanger do postulado de Heidegger e Husserl (Massimi, 2019; Evangelista, 2016; Dastur, 2015), referindo-se a uma compreensão pré-predicativa do que significa o tempo, rompendo a linearidade cronológica e constituindo um movimento dialético inerente à existência de ser-no-mundo. Na temporalidade humana descrita por Heidegger, a existência é um projeto e o existir é ser-possibilidade. Do ponto de vista psicopatológico, o paciente muda seu passado, dando ao seu futuro uma nova conformação; não cabe a nós afirmar uma ressignificação dos traumas, mas o desvelamento de novos significados da experiência prévia.

H. está agora com 48 anos. Considerando o desenvolvimento estrutural saudável, ele deveria estar vivendo um apogeu estável, em que seu passado fornece um terreno sólido para o desenvolvimento de suas possibilidades de vida, com muitas opções de interesses e intensa dedicação a projetos que constituiriam o grosso de sua vida produtiva. Deveria ser uma fase de muita alegria e plena produção, mas nada está mais longe do que é vivido por ele.

H. tem pouco contato com seu passado vivido, exceto o momento em que testemunhou o tiro do policial. Ele pode se lembrar de algumas informações sobre a infância, mas os detalhes não são acessíveis. Não é que ele não possa se lembrar dessa informação, mas ele está preso na presença de um desastre iminente que não permite que sua atenção e intencionalidade se dirijam para qualquer coisa que não a autopreservação. Como alguém que está caindo de um penhasco, nada em seu passado poderia fornecer qualquer ajuda, motivação ou ser interessante o suficiente para merecer atenção neste momento em que sua vida está em grande perigo. 
Raciocínio semelhante poderia ser usado para avaliar seu futuro vivido: não há espaço para planejar, desejar, sonhar ou esperar se ele não sabe se estará vivo no próximo segundo. Toda a sua intencionalidade futura visa evitar a morte/agressão iminente dele ou de parentes próximos. Preso a um presente hipertrofiado pelo medo, H. não conseguia construir nada de novo, ou desempenhar qualquer outro papel que não o de sobrevivente lidando com uma força avassaladora que pode aniquilá-lo a qualquer momento.

A temporalidade é vivida por ele como um presente infinito, com um passado que só é sentido como os últimos segundos relacionados à consciência imediata do perigo percebido. $\mathrm{O}$ futuro também não é mais longo do que os próximos segundos imediatos, dos quais ele só pode esperar a ameaça e tentar movimentos simples de defesa.

Na base fenomenológica, tanto Heidegger quanto Husserl (Peres, Assis \& Machado, 2019) seguem o pressuposto aristotélico de que o passado só é acessível pelo presente. Um movimento dialético para o futuro em aberto, em uma protensão de projetos entre as condições de possibilidades do ser-no-mundo e sua facticidade. No caso explorado, o que vemos é uma quebra desse movimento. A melhora clínica pôde ser observada como o retorno de algum movimento para o futuro, não relacionado com a prevenção de ameaça iminente.

Espacialidade

A espacialidade é aqui considerada, segundo o raciocínio heideggeriano (Camasmie, 2014), não como uma questão de espaço estritamente geométrico e físico; não se tem, nem se transita pela espacialidade, mas se tem como abertura do ser-no-mundo, vivenciada como condições de possibilidades de desprendimento/aproximação e direção/organização no mundo circundante. Assim, a espacialidade não se reduz à posição física do ser-aí, mas se abre no desvelamento de significados relacionados com o mundo. Assim, o espaço de convivência está vinculado à disposição afetiva de estar-no-mundo.

Descrito de uma perspectiva espacial, o mundo vivido pelo paciente é claro e luminoso, mas com esconderijos onde se escondem muitos perigos, o que o deixa sempre alerta. Seu estado de alerta lhe agracia com uma habilidade aguçada de perceber sons, movimentos ou áreas onde um atacante oculto poderia entrar, identificado por um estado de hipervigilância que o torna sempre ciente de qualquer mudança ao seu redor. Infelizmente, isso também diminui sua capacidade de concentração, trazendo um sério prejuízo na produção de sua vida. Isto contribui também para uma fonte constante de informações desconexas, que são racionalizadas pelo medo como evidência de uma ameaça iminente, conduzindo à construção de um mundo vivido onde está sempre sendo rastreado, observado e comprometido. 
Seu espaço vivido sofreu uma contração devido ao medo, e agora ele só é capaz de existir em um território superseguro e controlado. Desde o evento traumático, seu mundo vivido foi progressivamente reduzido pela necessidade de proteção e segurança, até que ficou restrito ao seu quarto, no início de seu tratamento. Mesmo depois de se sentir mais relaxado, com um pequeno, mas perceptível, alívio dos sintomas pela medicação, H. não ganhou território. Ele parece estar aliviado em seu terreno seguro sem medo, e está expandindo lentamente seu mundo vivido novamente, porém com o mínimo de riscos dos arredores de sua casa. É como se ele estivesse testando metro a metro, tentando saber se os arredores são seguros, antes de baixar a guarda e permitir sua livre circulação novamente.

Embora ele esteja circulando em algumas áreas comuns do cotidiano, como a padaria, um mercado e a escola de seus filhos, o território que o lembra do evento violento ainda está amputado de sua vida. Ele evita sistematicamente quartéis/departamentos de polícia, patrulhas policiais ou arredores do pessoal de segurança privada. Nessa estrutura, é possível observar uma restrição do "lá-compartilhado" do paciente ("aí-compartilhado" ou realidade/mundo vivido compartilhado) (Jardim, 2013), no desvelamento do seu ser-no-mundo, comprometendo suas condições de possibilidade. Experiências recentes, em que sua esposa tentou acompanhá-lo a um centro comercial, resultaram em um ataque de pânico alguns momentos após entrar no shopping.

\section{Interpessoalidade}

As habilidades empáticas parecem preservadas, pois ele não demonstra confusão ou incapacidade de compreender os sentimentos dos outros, e também é capaz de mostrar adequadamente seus sentimentos para outras pessoas e para o entrevistador, embora com certo entorpecimento. O contato interpessoal, entretanto, parece estar contaminado por seu medo. Ele parece desconfiado e sempre espera ser ameaçado ou agredido pelo entrevistador, com quem não se sente à vontade.

Esse paciente evoca no entrevistador sentimentos de extrema compaixão, como se estivesse lidando com uma criança com medo que merece proteção. É possível que aqui sua limitação intelectual marque seu contato com um sentimento permanente de ingenuidade, percebido como infantil. $\mathrm{O}$ aspecto de fragilidade e medo de seu contato interpessoal, no entanto, é sempre percebido. H. evita o contato visual quase o tempo todo, parecendo estar preocupado em atrair alguma raiva ou motivar um ataque do clínico.

O medo parece contaminar outras modalidades de ressonância afetiva. Ao sorrir, H. o faz como se estivesse preocupado em gerar sentimentos negativos no entrevistador. Ele descreve seus sentimentos em relação à esposa e aos filhos como se estivesse entorpecido por outras 
emoções, que podem ser o medo e a necessidade de segurança. É claro que suas preocupações paranoicas englobam seus entes queridos, como mostra sua necessidade de instalar rastreadores em sua esposa e filhos. Isso cria um padrão que divide as pessoas em dois tipos: os entes queridos, que precisam ser protegidos e estão sempre em perigo devido ao envolvimento com eles, e os outros potencialmente perigosos, dos quais ele precisa se salvaguardar e estar sempre desconfiado, como uma fonte de ameaça. Esse aspecto do mundo vivido de H. pouco melhorou desde o início do tratamento, exceto pela discreta melhora do relacionamento interpessoal com seu médico assistente.

\section{Materialidade (corporeidade)}

Na constituição da corporeidade, Van den Berg (2000) elucida a experiência dialética de ser corpo (corpo vivido) e de ter corpo (corpo vivenciado). O primeiro é pré-reflexivo, uma experiência cotidiana imediata dotada principalmente de percepção consciente do mundo. Aqui, a noção de conversão ou sintomas psicossomáticos é descartada, mas o imediatismo homemmundo sintético é considerado.

A presença de H. é elusiva. Ele não é nem pesado nem leve, mas está muito tenso, contraído e pronto para correr. Ele está sempre vestido demais, com jaquetas pesadas que parecem uma armadura. Sua inquietação corporal é perceptível pelos demais, esfregando as mãos, evitando o contato visual, mantendo uma postura defensiva durante toda a entrevista.

Ao cumprimentar, ele novamente parece fugaz. Ele aperta as mãos a distância, embora não evite o toque. Seu movimento é tenso e bastante calculado para permitir uma rota de fuga ou algum tempo para estudar uma ameaça em potencial, que parece esperar de todos. Seus olhos estão sempre rastreando o ambiente e aparecem assustados, perplexos, em busca do perigo em cada esquina. Todo esse estado de alerta se reflete em resposta fisiológica: H. estava, antes de ser medicado, continuamente taquicárdico e em tratamento para hipertensão. É como se ele estivesse sempre sob alta influência adrenérgica. Essa seria a resposta defensiva fisiológica de correr ou lutar, esperada de alguém que acaba de ver uma ameaça.

\section{Redução Fenomenológica}

Por meio das dimensões da vida analisadas em H., fica evidente a presença de um medo generalizado. O medo está sempre presente e é intenso, contaminando toda a sua existência, imprimindo marcas e consequências em suas expectativas, entorpecendo seu contato interpessoal, atraindo toda sua intencionalidade para a necessidade imediata de defesa. Isso 
prejudica suas habilidades construtivas e até mesmo seu pensamento, às vezes confuso, quase fragmentado e preso em um contínuo estado de defesa.

Para Heidegger (Evangelista, 2016), o medo é como um "estado de espírito": quando o sentimos, não revela necessariamente algo de temeroso do mundo, mas uma ameaça à nossa existência futura, protencional. No caso de H., em uma análise fenomenológica, o conceito de medo de Heidegger não explica a normalidade ou a patologia de seu medo, mas a compreensão de sua experiência assustadora em sua estrutura de ser-no-mundo. Sua experiência traumática faz com que sua abertura ao mundo seja assustadora, ele teme por ser-aí.

\section{Análise estrutural}

Esta é uma estrutura defensiva e alerta, com possibilidades mínimas de transcendência. A mobilidade é limitada pelas necessidades de reasseguramento, o contato com o passado vivido e o futuro vivido é fraco, pois a necessidade de defesa de uma ameaça imediata captura toda a intencionalidade. Nada importa quando está sob perigo imediato. Embora muito defendida, toda a estrutura parece tremer e entrar em colapso quando superexcitada por estímulos ambientais, resultando em ataques de pânico recorrentes.

\section{Diagnóstico por meio de análise da estrutura}

A investigação fenomenológica mostra uma estrutura marcada por intenso medo e evitação de uma ameaça esperada, embora não necessariamente presente. Algum movimento é possível, mas sob circunstâncias limitadas que requerem uma quantidade anormal de energia. A intencionalidade está presa em um estado de vigilância constante, o que prejudica sua capacidade de desenvolver ou adquirir novas características. Antecipar tudo no ambiente e qualquer contato com outros resulta em um estado paranoico que se cristaliza em um delírio persecutório.

O medo e a ameaça também contaminam a produção de seus sonhos, evidenciado por pesadelos recorrentes. Mesmo que não esteja presente neste caso, não seria inesperado que a relação de realidade, por meio da intencionalidade, fosse quebrada pela necessidade constante de alternar o foco da atenção entre os chamados da realidade (ex. Contato interpessoal) e a evitação de ameaças. Isso pode levar à desorganização e ao comprometimento da formação da memória, simulando transtorno formal do pensamento e amnésia. Tudo isso foi desencadeado por um evento violento que rompeu sua trajetória de vida, e causou uma restrição em sua estrutura. Essa parece ser a estrutura típica do TEPT. 


\section{Discussão}

A fenomenologia é o pano de fundo filosófico da psicopatologia continental (Parnas, 2011; Stanghellini, 2009; Tonus \& Messas, 2018). Seu uso para procedimentos diagnósticos e descrição de distúrbios, entretanto, é difícil e requer treinamento específico. Apesar disso, o uso da fenomenologia para diagnóstico estrutural e descrição de distúrbios traz algumas vantagens que não estão disponíveis em critérios operacionais e mesmo na psicopatologia descritiva (Messas et al., 2018).

Ambos os sistemas de diagnóstico operacional convencionais, DSM-5, CID-10 e sua décima primeira edição, descrevem o TEPT em torno de quatro "conjuntos" de sintomas dimensionais: Rememoração intrusiva (flashbacks, pesadelos etc.); evitação de estímulos; alterações de humor/cognitivas e hiperexcitação (American Psychiatric Association. DSM-5 Task Force, 2013; Organização Mundial da Saúde, 1992). Pelo menos um sintoma de cada grupo, deve estar presente, começando ou piorando alguns dias após um evento traumático e durando um mês. Mas, de uma perspectiva estrutural, foi mostrado que todos esses sintomas, como expressões do ser-no-mundo, são apenas acessórios para um medo persistente e penetrante, que se tornou patologicamente parte da estrutura consciente.

Pior ainda, a presença de características psicóticas como delírio e alucinação de qualquer tipo restringe as heurísticas diagnósticas em sistemas categóricos aos transtornos do espectro esquizofrênico, transtornos afetivos com características psicóticas e Transtorno Delirante Persistente (TDP). Mas aqui, demonstramos um paciente com antecedentes clínicos, evolução e resposta terapêutica que não são compatíveis com nenhum desses diagnósticos. Visto que a descrição do sistema de diagnóstico categorial desses transtornos já foi criticada por ter baixa validade (Aboraya et al., 2005; Jablensky, 2016), como a fenomenologia poderia contribuir para essa diferenciação? Uma vez que nossa hipótese principal é que a característica do TEPT é uma estrutura travada, em um instante de risco na análise da dimensão temporal, parece interessante separá-la da esquizofrenia e da psicose afetiva no aspecto relacionado ao tempo.

A depressão melancólica e a mania têm manifestações de estrutura temporal muito bem descritas (Binswanger, 1964; Bloc et al., 2016; Sass \& Pienkos, 2013a). Na melancolia, duas perturbações temporais são evidentes: redução do fluxo temporal e passado hipertrofiado (Fuchs, 2001; Straus, 1960). Na primeira, o tempo passou a ser vivenciado como lento, tornando todas as expectativas incomodamente distantes e enfadonhas, acompanhando o grande peso da experiência corporal (Sass \& Pienkos, 2013b, 2013a).

O passado hipertrofiado se apresenta com uma ênfase exagerada nas experiências sentidas e vividas, levando à ruminação de velhas escolhas, de fracassos e da "maldição do $e$ se" 
(Fuchs, 2013). Em outras palavras, a experiência temporal é aquela da infiltração de momentos retentivos, percebendo o futuro como já realizado, independentemente da experiência real (Dastur, 2015).

Um tempo vivido como lento, pode ser confundido com “tempo congelado", e não é incomum que o TEPT seja confundido com, ou considerado, uma comorbidade da depressão (Campbell et al., 2007; Elhai et al., 2011) em sua apresentação clínica. O mesmo poderia ser dito sobre o passado hipertrofiado, que se assemelha a uma experiência travada em um momento, mas ambos são clinicamente diferentes. Nosso caso de TEPT não tem passado hipertrofiado, uma vez que ele nem mesmo é capaz de se lembrar dele, estando trancado no próprio momento de perigo e no futuro imediato em que pode estar morto. Embora o fenômeno de compressão do tempo seja descrito em experiências traumáticas (Fayolle, Gil, \& Droit-Volet, 2015), o tempo não é experimentado como lento, e sim como muito rápido. Não é como se um minuto durasse um dia, mas como se todo o dia fosse vivido em um minuto. No caso deste paciente, isso não é apenas o que é sentido em uma experiência de "é como se", mas ele está preso no mesmo minuto desde o evento.

A mania pode ser descrita temporalmente quase no sentido oposto da depressão melancólica: um futuro tornado presente, com fluxo temporal aumentado (Binswanger, 1964; Ghaemi, 2006). Os planos para o futuro tornam-se tão rápidos em presente, que os pacientes costumam vivenciar seu desejo como já realizado, levando ao delírio de grandeza e de poder (Sass \& Pienkos, 2013a). O aumento da experiência do fluxo de tempo é visto como aumento da velocidade de pensamento, fala e comportamento, muitas vezes comprometendo a compreensão e levando ao hipopragmatismo, apesar do aumento da volição observada na experiência corporal (Figueira \& Madeira, 2011; Sass \& Pienkos, 2013b).

O presente caso tem um fluxo de tempo experienciado como acelerado, mas, novamente, está apenas bloqueado na experiência circundante imediata. Não é o mesmo que se observa na mania, pois pode parecer que o paciente não consegue mudar sua intencionalidade ou mesmo o conteúdo de suas preocupações. Pode-se dizer que vive uma realidade monotemática, recomeçando sempre um futuro imediato quando poderá estar em perigo, vivido muitas vezes no mesmo momento. Esses fenômenos são realmente diferentes da experiência de constante mudança e realização da mania (Figueira \& Madeira, 2011; Ghaemi, 2006).

A esquizofrenia é categoricamente descrita, principalmente, como uma síndrome delirante alucinatória, com componentes de desorganização do pensamento (American Psychiatric Association, DSM-5 Task Force, 2013). No entanto, Parnas descreve que esses sinais e sintomas são apenas consequências secundárias dos transtornos do eu, que são o núcleo clínico 
de todos os transtornos do espectro esquizofrênico (Parnas, 2011; Parnas \& Handest, 2003; Sass \& Parnas, 2003). Embora não desenvolvendo uma descrição temporal específica para a esquizofrenia, seu trabalho aponta que a característica estrutural da esquizofrenia é o comprometimento da capacidade de integrar as várias experiências conscientes subjetivas sutis, mas fundamentais, como resultado da perda de ipseidade (Møller, Haug, Raballo, Parnas, \& Melle, 2011; Parnas, 2011; Parnas \& Handest, 2003).

$\mathrm{Na}$ Avaliação das Experiências Anômalas de Si (Examination of Anomalous SelfExperience-EASE), é descrito um atraso ou prejuízo na experiência de propriedade (no sentido de posse) das vivências e uma infinidade de experiências relacionadas ao tempo, que é sentido como congelado, lento ou cronicamente apressado, entre outros (Parnas et al., 2005). A incapacidade de lidar com a integração entre as experiências vividas e o tempo é o problema real aqui e não uma perturbação específica do tempo, que poderia levar a experiências temporais de "é como se" bizarras. Isso é radicalmente diferente do que foi demonstrado no caso em apreço.

Nosso paciente certamente possui uma alteração do tempo vivido, mas é precisamente a experiência de estar sempre no mesmo momento de perigo que é característico de sua experiência vivida e de sua estrutura de consciência. Não foi demonstrado em nenhum momento de sua história ou exame mental a presença de qualquer outra alteração que pudesse ser descrita como transtorno do eu. Seus delírios e fenômenos alucinatórios parecem ser secundários aos danos de sua estrutura, no que é a única semelhança com a esquizofrenia (Parnas \& Sass, 2001).

Uma vez que a característica principal do TDP é um delírio bem estruturado, persistente e geralmente monotemático (American Psychiatric Association. DSM-5 Task Force, 2013; Organização Mundial da Saúde, 1992), é difícil encontrar uma descrição fenômeno-estrutural específica para ele, visto que o delírio é considerado, fenomenologicamente, uma alteração secundária dos transtornos do eu (Parnas, 2004; Sass et al., 2013). Sendo clinicamente distinto da esquizofrenia e das psicoses afetivas, o TDP é provavelmente uma manifestação isolada de outros transtornos com características paranoides, mas com uma personalidade preservada (Munro, 1991). Foi demonstrado aqui que nosso paciente tem um delírio monotemático e persistente, mas não é possível dizer que esteja estruturado.

Novamente, esse fenômeno é secundário a características temporais diferentes. Qualquer que seja o mecanismo de desenvolvimento delirante (perturbação perceptual ou racional) (Parnas, 2004), uma evolução ao longo do tempo seria necessária para sua elaboração. Os pacientes com TDP não estariam tão preservados, se cronicamente paralisados, em um único momento existencial. Ficar paralisado no mesmo momento em que sua vida está em risco, pode facilmente explicar o estado de alerta e as características paranoides descritas no mundo vivido 
de nosso paciente, sugerindo a presença de um delírio persistente a um observador externo. A imobilidade temporal também pode ser responsável pela ausência de desenvolvimento do delírio (que resultaria em sua sistematização), uma vez que sua estrutura está imobilizada naquele momento.

O medo é geralmente descrito como uma característica observada na análise espacial da estrutura esquizofrênica, conforme apresentado por Binswanger (2012) no caso Suzan Urban. A análise temporal de pacientes ansiosos (Aho, 2018) e as interações da estrutura espacial do melancólico (Tellenbach, 2014) também possuem seus traços. No entanto, é necessário dizer que, no TEPT, o medo não faz parte de uma resposta a um mundo vivido anormal, como acontece na resposta à falta de contato vital com a realidade da esquizofrenia, na esmagadora preocupação com o futuro observada na ansiedade, ou na dimensão espacial escura, pesada e sinistra de um melancólico.

No TEPT, um medo intenso, avassalador e sempre presente faz parte da estrutura, influenciando todas as experiências vividas pelo sujeito. Esse medo também é responsável por travar a estrutura em um momento de vida singular, paralisando o desenvolvimento existencial por meio da restrição da intencionalidade em movimentos defensivos. O medo não é apenas um "estado de espírito", mas um reflexo do modo de ser-no-mundo da estrutura do TEPT, manifestado como uma contaminação a sua abertura à existência na constituição da consciência. Esta é a essência fenomenológica do TEPT.

\section{Conclusão}

O diagnóstico categorial, embora seja considerado um ponto de inflexão revolucionário na psiquiatria moderna, sofre de problemas de validade (Andreasen, 2007; Jablensky, 2016; Parnas, 2011; Parnas et al., 2013). Defendemos uma descrição fenômeno estrutural, como uma construção diagnóstica mais válida do que uma lista de verificação de sintomas. Como foi demonstrado no presente trabalho, a ênfase exagerada em um sinal ou sintoma específico fragiliza um sistema categorial, e provavelmente leva a problemas de validade e confiabilidade.

No caso analisado, o delírio esteve presente e fazia parte da apresentação do TEPT. Excluir a possibilidade de delírio da descrição de TEPT provavelmente resulta em diagnósticos e tratamentos inadequados. Além disso, nenhum "distúrbio formal do pensamento" foi identificado, e o raciocínio apresentado aqui reforça a teoria das origens psicológicas do delírio, revogando a hipótese de esquizofrenia secundária ao TEPT (Seedat, Stein, Oosthuizen, Emsley, \& Stein, 2003). 
Até onde é de nosso conhecimento, nenhuma descrição estrutural anterior de TEPT havia sido feita. Apresentamos aqui uma análise fenômeno-estrutural de um paciente com TEPT, que pode ser usado como ponto de partida para futuras discussões diagnósticas. Como modelo preliminar, deve ser validado e posteriormente desenvolvido por outros estudos. Esperamos que o desenvolvimento futuro de uma descrição estrutural do TEPT aumente a sua validade diagnóstica e confiabilidade, com efeitos positivos para a pesquisa deste transtorno. 


\section{References/ Referências Bibliográficas}

Aboraya, A., France, C., Young, J., Curci, K., \& Lepage, J. (2005). The Validity of Psychiatric Diagnosis Revisited: The Clinician's Guide to Improve the Validity of Psychiatric Diagnosis. Psychiatry (Edgmont (Pa.: Township)), 2(9), 48-55.

Aho, K. (2018). Temporal experience in anxiety: embodiment, selfhood, and the collapse of meaning. Phenomenology and the Cognitive Sciences, 1-12. https://doi.org/10.1007/s11097-018-9559-x

American Psychiatric Association., \& American Psychiatric Association. DSM-5 Task Force. (2013). Diagnostic and statistical manual of mental disorders: DSM-5. (5th ed.). Arlington VA; Washington D.C.: American Psychiatric Association.

Andreasen, N. C. (2007). DSM and the death of phenomenology in america: an example of unintended consequences. Schizophrenia Bulletin, 33(1), 108-112. https://doi.org/10.1093/schbul/sbl054

Berger, W., Coutinho, E. S. F., Figueira, I., Marques-Portella, C., Luz, M. P., Neylan, T. C., ... Mendlowicz, M. V. (2012, June 18). Rescuers at risk: A systematic review and metaregression analysis of the worldwide current prevalence and correlates of PTSD in rescue workers. Social Psychiatry and Psychiatric Epidemiology. Springer-Verlag. https://doi.org/10.1007/s00127-011-0408-2

Binswanger, L. (1964). On the manic mode of being-in-the-world. In Erwin W. Straus (Ed.), Phenomenology: Pure and applied (pp. 127-141). Pittsburgh: Duquesne University Press.

Binswanger, Ludwig. (2012). O caso Suzan Urban. Psicopatologia Fenomenológica Contemporânea, 1(1), 198-344.

BLOC, L., SOUZA, C., MOREIRA, V., BLOC, L., SOUZA, C., \& MOREIRA, V. (2016). Phenomenology of depression: Contributions of Minkowski, Binswanger, Tellenbach and Tatossian. Estudos de Psicologia (Campinas), 33(1), 107-116. https://doi.org/10.1590/1982-027520160001000011

Brewin, C. R., Cloitre, M., Hyland, P., Shevlin, M., Maercker, A., Bryant, R. A., ... Reed, G. M. (2017). A review of current evidence regarding the ICD-11 proposals for diagnosing PTSD and complex PTSD. Clinical Psychology Review, 58, 1-15. https://doi.org/10.1016/J.CPR.2017.09.001

Bryant, R. A., McFarlane, A. C., Silove, D., O’Donnell, M. L., Forbes, D., \& Creamer, M. (2016). The Lingering Impact of Resolved PTSD on Subsequent Functioning. Clinical Psychological Science, 4(3), 493-498. https://doi.org/10.1177/2167702615598756

Camasmie, A. T. (2014) Espacialidade. Psicoterapia de grupo na abordagem fenomenológicoexistencial: Contribuições heideggerianas. 142-146

Campbell, D. G., Felker, B. L., Liu, C.-F., Yano, E. M., Kirchner, J. E., Chan, D., ... Chaney, E. F. (2007). Prevalence of Depression-PTSD Comorbidity: Implications for Clinical Practice Guidelines and Primary Care-based Interventions. Journal of General Internal Medicine, 22(6), 711-718. https://doi.org/10.1007/s11606-006-0101-4

Cheniaux, E. J. (2011). Manual de Psicopatologia (4a ed.). Rio de Janeiro: Guanabara Koogan.

Corbin, T. J., Purtle, J., Rich, L. J., Rich, J. A., Adams, E. J., Yee, G., \& Bloom, S. L. (2013). The Prevalence of Trauma and Childhood Adversity in an Urban, Hospital-Based Violence 
Intervention Program. Journal of Health Care for the Poor and Underserved, 24(3), 10211030. https://doi.org/10.1353/hpu.2013.0120

Dalgalarrondo, P. (2008). Psicopatologia e Semiologia dos Transtornos Mentais (2a ed.). Porto Alegre: Artmed.

Dastur, F. \& Cabestan, P. (2015). A obra fundadora de Ludwig Binswanger (1881-1966). Daseinsanalyse: Fenomenologia e Psicanálise. 64-101.

Durkin, M. E. (1993). Major Depression and Post-Traumatic Stress Disorder Following the Coalinga and Chile Earthquakes: A Cross-Cultural Comparison. Journal of Social Behaviour and Personality, 8(5).

Elhai, J. D., de Francisco Carvalho, L., Miguel, F. K., Palmieri, P. A., Primi, R., \& Christopher Frueh, B. (2011). Testing whether posttraumatic stress disorder and major depressive disorder are similar or unique constructs. Journal of Anxiety Disorders, 25(3), 404-410. https://doi.org/10.1016/J.JANXDIS.2010.11.003

Evangelista, Paulo Eduardo Rodrigues Alves. A existência. Psicologia fenomenológica existencial: a prática psicológica à luz de Heidegger. 85-122

Fayolle, S., Gil, S., \& Droit-Volet, S. (2015). Fear and time: Fear speeds up the internal clock. Behavioural Processes, 120, 135-140. https://doi.org/10.1016/J.BEPROC.2015.09.014

Figueira, M. L., \& Madeira, L. (2011). Time and Space in Manic Episodes. Dialogues in Philosophy, Mental and Neuro Sciences, 4(2), 22-26.

Franco, Sergio de Gouvêa. (2012). "Dilthey: compreensão e explicação" e possíveis implicações para o método clínico. Revista Latinoamericana de Psicopatologia Fundamental, 15(1), 1426. https://dx.doi.org/10.1590/S1415-47142012000100002

Fuchs, T. (2001). Melancholia as a Desynchronization: Towards a Psychopathology of Interpersonal Time. Psychopathology, 34(4), 179-186. https://doi.org/10.1159/000049304

Fuchs, T. (2013). Temporality and psychopathology. Phenomenology and the Cognitive Sciences, 12(1), 75-104. https://doi.org/10.1007/s11097-010-9189-4

Ghaemi, S. N. (2006). Feeling and Time: The Phenomenology of Mood Disorders, Depressive Realism, and Existential Psychotherapy. Schizophrenia Bulletin, 33(1), 122-130. https://doi.org/10.1093/schbul/sbl061

Groleau, D., Young, A., \& Kirmayer, L. J. (2006). The McGill Illness Narrative Interview (MINI): An Interview Schedule to Elicit Meanings and Modes of Reasoning Related to Illness Experience. Transcultural Psychiatry, 43(4), 671-691. https://doi.org/10.1177/1363461506070796

Hoffert, B. (2014). The Evil Hours: A Biography of Posttraumatic Stress Disorder. Library Journal, 139(13), 59. https://doi.org/10.1016/S0022-3913(12)00047-9

Hyams, K. C. (1996). War Syndromes and Their Evaluation: From the U.S. Civil War to the Persian Gulf War. Annals of Internal Medicine, 125(5), 398. https://doi.org/10.7326/00034819-125-5-199609010-00007

Jablensky, A. (2016). Psychiatric classifications: validity and utility. World Psychiatry: Official Journal of the World Psychiatric Association (WPA), 15(1), 26-31. https://doi.org/10.1002/wps.20284

Jardim, Luis Eduardo Franção (2013). Compreensão e Ação na Clínica Fenomenológica Existencial. Psicologia fenomenológico-existencial, 45-76 
Koda, M. Y., \& Fernandes, M. I. A. (2007). A reforma psiquiátrica e a constituição de práticas substitutivas em saúde mental: uma leitura institucional sobre a experiência de um núcleo de atenção psicossocial. Cadernos de Saúde Pública, 23(6), 1455-1461. https://doi.org/10.1590/S0102-311X2007000600020

Linhares, Shirley Ribeiro dos Santos, \& Paz, Elisabete Pimenta Araújo. (2020). The experience of tuberculosis treatment in Family Health Units. Escola Anna Nery, 24(2), e20190209. Epub 27 de feveiro de 2020.https://doi.org/10.1590/2177-9465-ean-2019-0209

Lopez-Ibor, J. J. (1948). El círculo timopático. Actas Luso-Espanolas de Neurologia, Psiquiatria y Ciencias Afines, $\operatorname{VII}(3)$.

Luz, M. P., Coutinho, E. S. F., Berger, W., Mendlowicz, M. V., Vilete, L. M. P., Mello, M. F., Figueira, I. (2016). Conditional risk for posttraumatic stress disorder in an epidemiological study of a Brazilian urban population. Journal of Psychiatric Research, 72, 51-57. https://doi.org/10.1016/j.jpsychires.2015.10.011

Massimi, Marina e Peres, Sávio Passafaro (orgs.) (2019). História da psicologia fenomenológica.

McHugh, P. R., \& Treisman, G. (2007). PTSD: A problematic diagnostic category. Journal of Anxiety Disorders, 21(2), 211-222. https://doi.org/10.1016/J.JANXDIS.2006.09.003

Messas, G., Fulford, K. W., \& Stanghellini, G. (2017). The contribution of human sciences to the challenges of contemporary psychiatry. Trends in Psychiatry and Psychotherapy, 39(4), 229-231. https://doi.org/10.1590/2237-6089-2017-0111

Messas, G., Tamelini, M., Mancini, M., \& Stanghellini, G. (2018). New Perspectives in Phenomenological Psychopathology: Its Use in Psychiatric Treatment. Frontiers in Psychiatry, 9. https://doi.org/10.3389/fpsyt.2018.00466

Møller, P., Haug, E., Raballo, A., Parnas, J., \& Melle, I. (2011). Examination of anomalous selfexperience in first-episode psychosis: interrater reliability. Psychopathology, 44(6), 386390. https://doi.org/10.1159/000325173

Munro, A. (1991). Phenomenological Aspects of Monodelusional Disorders. British Journal of Psychiatry, 159(S14), 62-64. https://doi.org/10.1192/S0007125000296505

Parnas, J. (2004). Belief and Pathology of Self-awareness A Phenomenological Contribution to the Classification of Delusions. Journal of Consciousness Studies, 11(10-11), 148-161.

Parnas, J. (2011). A disappearing heritage: the clinical core of schizophrenia. Schizophrenia Bulletin, 37(6), 1121-1130. https://doi.org/10.1093/schbul/sbr081

Parnas, J., \& Handest, P. (2003). Phenomenology of anomalous self-experience in early $\begin{array}{llll}\text { schizophrenia. } \quad \text { Comprehensive } & \text { 121-134. }\end{array}$ https://doi.org/10.1053/comp.2003.50017

Parnas, J., Møller, P., Kircher, T., Thalbitzer, J., Jansson, L., Handest, P., \& Zahavi, D. (2005). EASE: Examination of Anomalous Self-Experience. Psychopathology, 38(5), 236-258. https://doi.org/10.1159/000088441

Parnas, J., \& Sass, L. A. (2001). Self, Solipsism, and Schizophrenic Delusions. Philosophy, Psychiatry, \&amp; Psychology, 8(2), 101-120. https://doi.org/10.1353/ppp.2001.0014

Parnas, J., Sass, L. a., \& Zahavi, D. (2013). Rediscovering psychopathology: The epistemology and phenomenology of the psychiatric object. Schizophrenia Bulletin, 39(2), 270-277. https://doi.org/10.1093/schbul/sbs153 
Rosenhan, D. L. (1973). On being sane in insane places. Science (New York, N.Y.), 179(4070), 250-258.

Santiago, Clarisse; Leal, Erotilde; Serpa Jr, O. (2014). Narrative as a tool in medical education: the use of the McGill illness narrative interview, 4.

Sass, L. A., Pienkos, E., Fulford, K. W. M., Davies, M., Gipps, R. G. T., Graham, G., ... Thornton, T. (Ed). (2013). Delusion: The phenomenological approach. In G. Fulford, W; Davies, M; Graham, G; Daler, J; Stanghellini (Ed.), The Oxford handbook of philosophy and psychiatry, 632-657. Oxford: Oxford University Press.

Sass, L. a, \& Parnas, J. (2003). Schizophrenia, consciousness, and the self. Schizophrenia Bulletin, 29(3), 427-444.

Sass, L., \& Pienkos, E. (2013a). Space, Time, and Atmosphere A Comparative Phenomenology of Melancholia, Mania, and Schizophrenia, Part II. Journal of Consciousness Studies, 20(78), 131-152(22).

Sass, L., \& Pienkos, E. (2013b). Varieties of Self-Experience: A Comparative Phenomenology of Melancholia, Mania, and Schizophrenia, Part I. Journal of Consciousness Studies, 20(78), 103-130.

Seedat, S., Stein, M. B., Oosthuizen, P. P., Emsley, R. A., \& Stein, D. J. (2003). Linking Posttraumatic Stress Disorder and Psychosis. The Journal of Nervous and Mental Disease, 191(10), 675-681. https://doi.org/10.1097/01.nmd.0000092177.97317.26

Stanghellini, G. (2009). The meanings of psychopathology. Current Opinion in Psychiatry, 22(6), 559-564. https://doi.org/10.1097/YCO.0b013e3283318e36

Stanghellini, G. (2010). A hermeneutic framework for psychopathology. Psychopathology, 43(5), 319-326. https://doi.org/10.1159/000319401

Straus, E. (1960). Das Zeiterlebnis in der endogenen Depression und in der psychopathischen Verstimmung. In Psychologie der Menschlichen Welt, 126-140. Berlin, Heidelberg: Springer Berlin Heidelberg. https://doi.org/10.1007/978-3-642-87995-1_4

Tellenbach, H. (2014). A Espacialidade do Melancólico. Psicopatologia Fenomenológica Contemporânea, 3(2), 73-108.

Tonus, A., \& Messas, G. (2018). Ludwig Binswanger: the construction of an epistemological foundation for psychiatry. Circumscribere: International Journal for the History of Science, 22, 36-49. https://doi.org/10.23925/1980-7651.2018v22;p36-49

Van den Berg, J. H. (2000). O Paciente Psiquiátrico: Esboço de uma psicopatologia fenomenológica.

Weathers, F. W. (2017). Redefining posttraumatic stress disorder for DSM-5. Current Opinion in Psychology, 14, 122-126. https://doi.org/10.1016/j.copsyc.2017.01.002

Wilson, M. (1993). DSM-III and the transformation of American psychiatry: a history. American Journal of Psychiatry, 150(3), 399-410. https://doi.org/10.1176/ajp.150.3.399

Wing, J. K. (1990). SCAN. Archives of General Psychiatry, 47(6), 589. https://doi.org/10.1001/archpsyc.1990.01810180089012

World Health Organization. (1992). The ICD-10 Classification of Mental and Behavioural Disorders: Clinical Descriptions and Diagnostic Guidelines. World Health Organization.

World Health Organization. (2018). International statistical of diseases and related health problems (11th Revision).

Psicopatologia Fenomenológica Contemporânea, 2021;10(1):39-75 